УДК 81'1:159,9

DOI 10.31.65/2520-6966-2020-14f-98-163-176

О. А. Зеленько

кандидат медичних наук, доцент кафедри загальної психології Київського національного університету імені Тараса Шевченка

\title{
Про функційне формування психічної діяльності на свідомісному етапі
}

Автором визначаються взаємозв'язані загальна соціальна й часткова наукова проблеми. Вони ним кваліфрікуються як актуальні, що (бачиться йому) мають розв'язуватися науково, зважаючи на засилля популізму, посталого реакцією на успадкований з недалекого минулого всесильного бюрократизму.

Автор бачить вирішення часткової й опосередковано загальної проблем опертям на регенеровану ним категорію методології у вигляді парадигмально сформульованої соціальної педології. Вона сформована на основі осмислення, зважаючи на сучасну ситуацію у галузі, тріадної фрізіологопсихо-соціальної категорії загальної категорії свідомості, яка антропологізується суб'єктивізованим об'єктом дослідження у вигляді елітника, що має демократизувати суверенну Україну. Розв'язувана проблема трансформування вищої школи постає засобом інтенсифрікування підготовки у соціально-рівневому елітному університеті резерву реформаторів, що мають замінити успадкованих з минулого бюрократичних ффункціонерів. Наголошується також на міжпредметності вирішуваних проблем, синтезі психології та мовознавства.

Ключові слова: демократизація, елітник, ізоморфізм, когнітивізм, рефоормування, свідомість, трансформування.

Стаття перегукується зі спадком визначних вітчизняних психологів. Йдеться про філософсько-гносеологічні традиції та про поєднання ними поставлених і вирішених проблем в гуманітарному соціальноприкладному аспектах. Фактично мова заходить про загальну соціальну та часткову гуманітарну лакуни, що далі констатується. Автор бачить їх вирішення у сучасному їх парадигмально-когнітивному варіанті. Пройдені допарадигмальний, макро- й мікроструктурний етапи логічно мали б підсумуватися теоретичним функціональним. Знехтувана фрізіолого-емотивно-соціальна (у радянській психології) тріадна свідомість, а з нею пов'язаний свідомісний елітник - наслідки нехтування психологічних категорій, пов'язаних 3 визначенням явищ аутизму, савантою, шизофренією. Але в основному зумовлені недостатньою увагою до функціонування психічної 
діяльності на свідомісному етапі. Автор відштовхується від повсякденно чутої думки, що причина усіх негараздів у головах людей. А просвітницьке застереження радянських фрілософрів на адресу російських реформаторів на завершальному етапі заявленої перебудови про необхідність визначитися у реформуванні, бо, виявляється, трансфрормуванню Європи передувала ідеологія просвітництва, підказує, з чого слід починати. Аналіз загальної соціальної й часткової наукової проблем у психології актуалізований осмисленням сучасної ситуації у суверенній Україні та у психології, яку позбавляють статусу галузі науки, штучно перериваючи спадкоємний зв'язок її зі здобутком класиків вітчизняної психології й відповідно дослідженнями сучасних науковців. Питання про загальне соціальне тло автором зачіпається побіжно. Він же зосереджується на ситуації у психології, де під кутом зору розв'язку згаданої соціальної проблеми, актуалізуючи категорію діалектики, зосереджується на категорії свідомості. Констатована ситуація у психології як галузі пояснюється ідеологічно соціальною ситуацією в Україні, й діагностується її функціональним превалюванням в умовах демократії категорії свідомості, тоді як засилля бюрократії асоціюється 3 категорією мислення.

Категорії функціонування й розвитку взаємозв'язані, бо розвиток - це ланцюг етапів фрункціонування. Розвиток діагностується діалектикою становлення будь-якого об'єкта, зокрема суб'єктивізованої, антропологізованої категорії свідомості як вищої фооми родової категорії психічної діяльності у нормі здорової психічно людини й відхиленнях у людей психічно хворих чи з особливими потребами. Не дивно, що у центрі дослідження автором ставиться питання про формування психічної діяльності, зокрема ії вищої форми на свідомісному етапі. Соціальне фрункціонування людини як носія антропологізованої свідомості у діалектиці її відтворення й робиться предметом розгляду цієї розвідки.

Започатковується ж діалектика аналізу соціологізованої психолого-фізіологічної взаємодії людини з середовищем залученням забутих спадків вітчизняних психологів Х. А. Екеблада [23] про тріадність психологічної діяльності, М.Я. Грота [1; 2] про тріадність її вищої форми свідомості та тріадність (фрізіолого-психоло-соціального) процесу пізнання Г. І. Челпанова [21; 22], антропологізованого носія категорії свідомості елітника, носія соціальної форми взаємодії, власне соціальної фрорми функціонування матерії [8; 9]. Зауважимо, що знехтувана в успадкованій з радянського етапу українській психології класика опирається на сучасну європейську когнітивну парадигму (а також у лінгвістиці), й ними вже пройдена у 
іiї початковому становленні. Когнітивна парадигма, підсумована у мовознавстві науковим допарадигмальним етапом, надалі посталими макроструктурним компаративізмом, який мікроструктурно через лінгвістичний структуралізм підсумувався проміжним між ним та підсумковим на сучасному етапі когнітивізму саме фрункціоналізмом. До речі, саме визначення універсального мема у вигляді фронеми було ініційоване у гуманітарії фрункційним принципом, який поки що сприймається з потугами. Його утвердження констатоване усвідомлено автором дослідження на психологічному, проміжному між фрізіологічним та соціальним етапами розвитку матерії трансформування відчуття у почуття.

Спроба нинішньої популістської урядової команди в Україні керувати країною не пошуком правди (істини) у традиційних парламентських дискусіях, а пропагуванням нав'язуваного надуманого розв'язку, бо люди не люблять правди й значно легше розв'язувати проблеми за допомогою утверджування сконструйованих мас-медією моделей, уже нині часом протиставляє урядовців українському суспільству. Не додає оптимізму носіям популістської ідеології спроба уточнити ії синтезом лібералізму та соціалізму. Виявляється, застереження радянських фрілософрів про необхідність в ідеологічному визначенні поки що командою не сприйняте. Вина нинішніх рефрорматорів у низькому освітньо-цивілізаційному рівні, який вони сподіваються подолати, започаткувавши формування української політичної еліти. Але без визначеності в ідеології й з нею зв'язаною науковою методологією не лише часткову психологічну наукову, а тим паче загальну соціальну лакуну не ліквідувати й демократизацію суверенної України не здійснити. Популізм і догматизм у кінці XIX й початку XX ст. дається взнаки, як бачимо, у процесі реформування суверенної України. На жаль, як не вистачило зусиль для осмислення демократизації Росії, так в суверенній Україні поки що ідеологічне просвітництво не виконує свого призначення. Пояснюється те справді порівняно невисоким соціальним розвитком не лише пересічних громадян (найперше Півдня й Сходу України), але й квазіеліти України (не лише політичної, але й наукової).

Отже, знову мова заходить про наукову методологію та ідеологію. Як свідчить практика, найгірша ситуація у співвіднесенні методології та ідеології у бюрократичному суспільстві. Йдеться про Україну, представлену ліберальним бюрократизмом. Стандартом ситуації слід кваліфікувати ситуацію в СРСР, де вождь визначив свою по-різному модифіковану марксистську ідеологію. Врештірешт усе те там підсумувалось (особливо у гуманітарних галузях) масовим догматизмом і боротьбою з дисидентами. В таких умовах 
сформувалися дві наукові лакуни, ліквідація яких стала предметом аналізу низки проблем, зокрема визначених автором розвідки й наукового дослідження. На основі розв'язку їх написана стаття. Вирішення їх бачиться автору в аспекті міжпредметності, яка фрактично, а не на словах пропагованою, бюрократично успадкованою освітньо-педагогічною атестацією МОН підмінюється спробою догматичного керування за допомогою пошуку плагіату. Свідоме (чи підсвідоме, очевидно) популістське оперування свідомістю (підсвідомістю) більшості пересічних людей продемонстроване класично у націонал-соціалістській Німеччині й Радянському Союзі. Не хотілося $б$ подібного у суверенній, демократично орієнтованій Україні, яка виборсується з обіймів середньовічної мілітарної Росії. До речі, міжпредметність як умова реалізації принципу наукового дослідження в автора уже завершуваної роботи відзначалася науковцями-фізіологами [5; 6; 7]. Комплексний розвиток психологічної лакуни автору не бачиться без звернення психологів (йдеться про когнітивістів) до іншої гуманітарної галузі. Міжпредметність як принцип наукової постановки й розв'язку проблеми про мовну діяльність як етап психічної автором уже засвідчена опублікованими ним самим чи у співробітництві з колегою розвідками [5].

На жаль, синтез психології й мовознавства долається якоюсь мірою когнітивістами у мовознавстві й значно гірше у психології, що засвідчила небезуспішна спроба європейського дослідника Річарда Докінза [4] проаналізувати ізоморфрізм генного та мовного кодів. До речі, якщо авторами, науковцями / методологами - філософами про парадигми у мовознавстві досить кваліфріковано проінформовано, то стосовно психології цього не зроблено. Досить ознайомитися з методологічним коментарем еволюції лінгвістики та психології у посібнику науковців Київського університету імені Тараса Шевченка [15]. До речі, сучасники-колеги цього елітного у минулому вітчизняного університету фрактично підсвідомо повертаються до гносеологічної дискусії емпіриків та апріористів, в якій активну роль відігравав їх попередник фрілософ і психолог Г. І. Челпанов [6; 7]. Насправді еволюційно складений процес функціонування головного мозку такого примітивізму не сприймає. Адже фрізіологічна фрорма взаємодії елементів матерії підсумувала механічну, фізичну, хімічну. Процеси диференціації й структуралізації ускладнюються й опосередковуються. Фізіологічна психологія тварин демонструє еволюцію сформування психіки у процесі все зростаючого опосередкування, підсумованого соціологізацією. До речі, те було констатоване фізіологом і психологом, дослідником психічної діяльності тварин та людей [18]. Надалі має йтися про психо-свідомісний спадок 
М. Я. Грота [1; 2] та Г. І. Челпанова [6; 7]. У ньому діалектика свідомісного процесу у нормі постає гармонійною взаємодією фрізіологічного, емотивного та вольового (відповідно соціального) компонентів в інтерпретації психологів особливо прозора. Якоюсь мірою тому мала б сприяти поки що недостатньо використовувана дослідницька діяльність гуманітаріїв-лінгвістів, що буде далі особливо переконливо продемонстровано.

Під цим кутом зору слід звернути увагу як на особливості фрізіологічної будови головного мозку, так й особливості структурної будови мовної системи, власне моделі світу. Під цим кутом зору варто звернути увагу також й на еволюційні варіанти з'яви-писемності у різних спільнот. При цьому не слід забувати про спадкоємне еволюційне їх використання. Про те мова піде далі, коли характеризуватиметься вольовий (соціальний) етап формування свідомості як вищої форми психічної діяльності на свідомісному етапі у вигляді мовної діяльності. У тварини наочно-дійове мислення (як психо-фрізіологічна категорія) реалізується несвідомісно на основі генетично сорормованого інстинкту. Емотивний супровід предметно, а не диференційовано розчленований. У людини він підсвідомо сприймається й, еволюційно узагальнюючись та абстрагуючись, поступово починає структурно диференціюватись, постаючи мовною системою. Свідомісне (точніше підсвідомісне) виділення людини не одномоментне й не однозначне, про що свідчить первинне (щодо часу й місця) іï уособлення. У процесі цивілізаційного розвитку абстрагування й узагальнення формується релігією структурована етнічна підсвідомість. Отже, мова заходить про перше природне дзеркало становлення (поки що) підсвідомості людини, зумовлене діянням гармонії.

Спрощені фрізіолого-вольові (соціальні) спроби налагодити толерантне соціальне функціонування громадян, нехтуючи пошуком гармонії соціального фрункціонування, продемонстровані, здавалося б, успішними на початковому етапі у націонал-соціалістській Німеччині та Радянському Союзі, засвідчили цивілізаційну безперспективність. Під цим кутом зору як не згадати зауваження Уїнстона Черчіля з приводу демократії як засобу вираження соціальної толерантності у соціальному організмі. Справді, йдеться про визнання необхідності пошуку соціальної гармонії колишнім главою Великобританії за допомогою демократії; заміну їй, на жаль, не знайшли: поки що нема чим компенсувати. Виявилось, до речі, що у випадку складних глибинно ситуаціях підсвідомо встановлюваний комунікативно-когнітивний елемент, як правило, емотивно забарвлений.

Повертаючись до діалекта психіки, констатуємо, до речі, соціальний етап мовної діяльності (за Г. І. Челпановим) еволюції усієї психіч- 
ної діяльності асоціюється з вольовим (за М. Я. Гротом) компонентом категорії загальної психології свідомості. Підказується те виявлюваною зміною функціонування правої (емотивної) та лівої (понятійної) півкуль головного мозку савантів. Фактична тотожність емоційних станів дорослої шимпанзе та дитини до року, що не розмовляє, підказує фізіолого-емотивно-соціальне становлення категорії свідомості за участю трьох складових категорії свідомості, а відповідно різних ділянок головного мозку. На користь діалектики категорії свідомості свідчить заборонна народна традиція не давати дитині до року дивитися у дзеркало. Соціальна фрізіологічна поведінка опосередковано регулюється й контролюється через емоційний компонент, а він у свою чергу має бути усвідомлений, контрольований та регульований. Індивідуальна поведінка визначається на основі успадкованої чи набутої (вихованої) релігійно, етнічно опосередкованої емотивної складової. Таким чином, свідомісний етап психічної діяльності утверджується вітчизняними психологами тріадною фізіолого-емотивно-вольовою компонентною структурою, а започатковується предметно конкретним відчуттям. Відчуття, що трансформується повторенням і синтезом з іншими відчуттями, трансформуючись у почуття, ффункцію комунікації-взаємодії доповнюють потенційною когнітивною, яка розгортається структурною змістовою здатністю розчленовуватись, втрачаючи якимись елементами емотивний компонент.

На початковому цивілізаційному етапі люди слабко виділяють себе серед тварин, з якими вони співіснують, залишаються дітьми природи і підпорядковуються закономірностям взаємодії з природою. З часом посилюється соціологізація, і людина, долаючи їх, все більше опосередковує цю взаємодію. Сонячні діти, генетично замкнені, цю взаємодію не соціологізують, бо генетично запрограмовані. Більшість же індивідів по-різному у різний час з різним співвідношенням змістових компонентів свідомості цей поріг долають. На користь визнання діалектики свідомості свідчить констатація того, що після оволодіння мовою діти на якомусь етапі не розуміють переносного значення слова. Мовний відчуттєвий комунікативний сигнал якийсь час не набуває здатності трансформуватися у повноцінний когнітивний знак. Психологічне природне дзеркало не трансформується якийсь час у повноцінне соціальне. Те відбувається на основі виділеного М.Я. Гротом вольового компонента свідомості. Зрозумілою стає активна роль суб'єктивного чинника у соціальному розвитку. Визначений ученим вольовий компонент, безумовно, соціальний, бо він постає й фрункціонує на етапі формування психічної діяльності, коли фізіологічна, опосередкована почуттєво-емотивно взаємодія повтор- 
но опосередковується, регулюючись структурованою диференційовано членованою взаємодією за допомогою утверджуваної звукової членороздільної мови, заступаючи позавербальний первинний супровід. Трансформування відчуттєвого фрізіологічного в емотивний психологічний у процесі інтенсифікованої соціалізації членороздільної мови, яка відсуває позавербальний супровід, підказується, зокрема, й іншими фрактами й припущеннями. Так, заслуговує на увагу констатація автором розвідки того, що реєстр емотивних станів дитини до року і дорослої шимпанзе фрактично тотожні. Логічно сприймається те, що шимпанзе могли елементарно сприймати й відтворювати протомовою нескладні ситуації. Беремо до уваги й припущення деяких дослідників, ніби дорослі шимпанзе здатні фоормувати мову за допомогою пересувних кубиків. Зрозуміло, що до структурованого фронемного відтворення тексту спілкування примати не могли дійти, хоча вони емотивно марковані елементи взаємодії, можливо, могли взаємопов'язувати. Під таким кутом зору теорія звукосимволізму у процесі фрормування звукової членороздільної мови набуває вірогідності.

Постає черга звернутись до третього компонента свідомості. Творче сфрормування вольового (соціального) компонента по-іншому орієнтує бачити деякі фракти. Об'єктивність вольового (соціального) компонента свідомості підтверджується згадкою про надмірну увагу при вивченні граматики латинської мови у класичній гімназії, так і двадцятиодноденною методикою Керолайн Ліф [11] за допомогою Бога свідомісно утвердитись у житті за тижневою прагматичною методикою трансформування поведінки [19] людини. Як рекомендації зарубіжних авторів переусвідомитися й змінитися позитивно, так і надокучливе зубріння граматичних форм та текстів латинських авторів орієнтовані на людей освічених, з характером, бо спадковий дворянин персонаж класика російської літератури Обломов на елітника не претендує. До речі, значущість вольового компонента у фрізичному (фрізіологічному) одужанні демонструється історією хворого пацієнта з новели класика американської літератури. Органічний матеріальний генний фрізіологічний процес функціонування соціальної істоти у людини не просто трансфрормувався в ідеальний опосередкований мемний (не лише на основі природної мови, але й інших систем), але йому підпорядкувався. На сучасному етапі бачимо, що він матеріалізувався комп'ютерно. Таким чином констатується свідомісний регістр психічної діяльності нормальної людини від елітника, в якого фрізіологічний та емотивний компоненти гармонізуються соціальним, і людей хворих психічно та з особливими потребами визначається на основі тріадно взаємодіючих підсистем. 
На жаль, поки що психологи фрактично не використовують динаміку структурної організації мовної моделі світу для виявлення еволюційного становлення психічної діяльності, зокрема й еволюції становлення свідомості. Академічне уявлення мовної системи не асоціюється з мовною моделлю, концептами, бо химерне представлення тексту поза мовою як засобом ії̈ матеріалізації свідомісної психічної діяльності стало на перешкоді повноправного утвердження когнітивної лінгвістики та когнітивної психології. Те все стало предметом аналізу когнітивістів, які зосередилися на традиційно визначуваному співвідношенні мови та мислення [10]. Зокрема, функційне визначення абстрагованої універсальної мовної одиниці напередодні утвердження когнітивної лінгвістики (й паралельно когнітивної психології) стало реальним усвідомлення звукової членороздільної мови як соціального структурування психічної діяльності (на свідомісному етапі) у вигляді мемів різного ступеня узагальнення й абстрагування, що постали на органічному генному [4]. Неважко зрозуміти, що рівні мовного структурування від тексту до звука мови у вигляді звукової фонемної підсистеми, морфеміки, словозміни, словотвору, синтаксису (членів речення й синтаксичних еквівалентів) - це структурування мовної (як етапу психічної) діяльності. Саме так постає теза про розрізнення мовної та психічної діяльності Вільгельма фрон Гумбольдта, та тлумачення про другу сигнальну систему І. П. Павлова синтезуються когнітивною психолінгвістикою. Констатується, що первинне підсвідомісне виділення людини на етапі її демократичного функціонування підсумовується усвідомленим пошуком абсолютизованих соціальним компонентом свідомості (гармонією взаємодії з ноосфрерою) за допомогою членороздільної звукової мови на другому соціальному етапі, що постав над генетичним фрізіологічним. Трохи далі піде мова про посталий над цим другим етнічним соціальним надетнічний соціальний, третій. Слід наголосити, що соціальний етнічний узгоджується 3 фізіологічним, так названий міжетнічний соціальний узгоджується з першим опосередкованіше, більше й менш опосередковано - з попереднім соціальним.

Прикро, що до останнього часу психологічна категорія свідомості емотивна гармонія здебільшого асоціюється 3 мистецькою розкішшю, тоді як це когнітивна складова комунікативної членороздільної звукової мови в її універсальному вигляді. На жаль, успадкована з СРСР псевдонаукова освітньо-педагогічна атестація бюрократизацією контролю за науковцями, нівелюючи гуманітарні галузі науки, механічним пошуком плагіату остаточно заперечила міжпредметність. I це при тому, що цим не могли похизуватись вітчизняні дослідники теорії мовознавства. До речі, питання функціонування мови, 
скажімо, Х. А. Екеблад віддавав Богові. Чи не тому класики й сучасні дослідники мовну діяльність фрактично не пов'язували з психічною або роблять це примітивно. Традиційно академічна граматика фактично не зважала на психологію. Стосовно ж лінгвістичного аспекту, то не слід нехтувати тим, що фрункційні системи у мові як системі кожна сама по собі виділяють свої рівні, бо вони постають наслідками абстрагування та узагальнення процесів структуралізації психічної діяльності на етапі мовної діяльності. Не дивно, що численні публікації, що висвітлювали питання про співвідношення мови та мислення до останнього часу, коли фрактично когнітивісти-дисиденти у суголоссі із зарубіжними колегами змінили характер досліджень, були далекі до наукової проблемності європейських та світових колег. Мабуть, нині немає підстав констатувати, що саме в гносеологічному аспекті логічно сприймаються українськими фрундаменталістами тези про вроджену потенцію розвитку мови Н. Хомського, теорія відповідності Е. Сепіра - Б. Уорфра, теорія звукосимволізму, ізоморфізм генного й мовного кодів Р. О. Якобсона - Г. В. Гамкрелідзе, теорія інтеріоризації Л. С. Виготського. Не дивно, що сподіватися тут доводиться й надалі на європейських та світових колег. I це при тому, що в даному аспекті відчувається превалювання не гуманітарної науки, а тепер утверджуваної комп'ютерології, яка навіть на побіжний погляд мала б успішніше розвиватися, використовуючи уже визначені категорії та методики лінгвістики, а не продовжувати це пошуком проб та помилок. I це тим більше, що гуманітарний характер науки не викликає сумніву.

До речі, слід звернутися до вже забутих лінгвістичних спроб з боку лінгвістів. Безуспішна спроба соціальний мем пов'язати з фрізіологічним геном М. Я. Марром [14] й відповідно пошук соціальних цивілізаційних джерел мема М. М. Вашкевича [1] у Середземномор"ї й П. Я. Лукашевича у дослов'янському [12; 13] континіумі дають підстави синтезувати психічну й мовну діяльність й визнавати ізоморфрізм генного й мовного кодів. Стає логічним фрізіологічний ген як конкретний матеріальний органічний елемент співвіднести з абстрактним матеріально вираженим мемом звукової членороздільної мови. Беремо до уваги фрактично підказану Річардом Докінзом [4] тезу про ізоморфізм генного та мемного (мовного) кодів. Здається, саме цей учений мимохіть, не концентруючись на категорії психічної діяльності, зокрема її вищої форми свідомості, започатковану проблему про співвідношення психічної та мовної діяльності поєднує з ученням про другу сигнальну систему, як і зі спробою про визначення фрункційного співвідношення гена та мема, що було актуалізоване Р. О. Якобсоном у вигляді ізоморфізму мовного та генного кодів. Пере- 
конуємось, що підсвідомо розв'язуваному нині питанню про ізоморфізм генного й мовного кодів, виявляється, передувала спроба П. Я. Лукашевича. Незалежно від нього, так би мовити, мемну систему став регенерувати М. М. Вашкевич. Беремо до уваги спроби П. Я. Лукашевича [12; 13] віднайти універсальні загальнослов'янські меми й сформувати загальнослов'янську мемну систему та М. М. Вашкевича [1]. Останній зробив також спробу поза зв'язком з психологією віднайти мем на основі російсько-арабської абракадабри. Започатковуємо констатоване згадкою, що геніальна спроба у теоретичному мовознавстві розв'язати питання про ізоморфрізм генного та мовного кодів М. Я. Марром, абсолютизуючи соціологічний аспект на шкоду психологічному, дала підстави для виділення лінгвістичної парадигми, але не вирішила проблему. Чотирьохелементний аналіз М. Я. Марра [14], його подальша соціалізація - це спроба на основі універсальних одиниць прослідкувати за закономірностями смислової (понятійної) структурованої дифреренціації психічної діяльності поза аналізом структури свідомості, зокрема й нехтуванням емотивного їі компонента. Законодавче утвердження в Україні он-лайну у сфері фінансів та бізнесу символізує початок прилучення українського суспільства до сучасної (європейсько-північноамериканської) он-лайнової смислової цивілізації. Вона взагалі стає передумовою повноцінної комунікації з європейцями та північноамериканцями. Бачимо, що у радянські часи представлена ворожим жупелом утверджувана насильно англоамериканська асиміляція постала європейською цивілізаційністю. Підсумована Р. О. Якобсоном та Г. В. Гамкрелідзе проблема ізоморфрізму генного та мовного кодів в інтерпретації Річардом Докінзом [14] соціального мема як спадкоємця органічного фізіологічного гена стає методологічною базою утвердження он-лайнової когнітивної комунікації. Пояснюється те в аспекті гносеологічному: категорія зміни матерії на рівні фрізіологічної взаємодії (на її вищому етапі) абсолютизовану комунікативну функцію (спілкування) поступово через психолого-емотивне опосередкування поєднує з когнітивною (пізнавальною). Ця фрункція на свідомісному рівні функціонування психічної діяльності реалізується посталою на генетико-соціальній етнічній звуковій членороздільній мові як формі мовної діяльності, що писемним її варіантом трансформується в універсальний міжетнічний соціальний засіб комунікації землян знову ж таки через посередність міжнародної мови англо-американської експансії. Нерозуміння етапності у переході від генного до мемного типів комунікації було причиною того, що квантитативної генетики, відтворивши генну еволюцію від мамонта до слова, поки що не можуть реалізувати її стосовно неандертальця (тим паче кроманьйонця) та сучасної людини. 3 
позицій сучасника-когнітивіста це пояснюється нехтуванням ролі ускладнюючого когнітивну комунікацію соціального мема. Як не прикро, але спадки М. Я. Марра, багатогранного ученого, теоретика мовознавства, його попередника однокурсника Миколи Гоголя, автора чудернацької чаромуті П. Я. Лукашевича, сучасника, аматора-мовознавця, військового перекладача-арабіста, автора таємничої абракадабри М. М. Вашкевича - це попередні ланки обґрунтування взаємодії через спілкування індивідів на етапі переходу поки що все ще абсолютизуючо функціонуючого етнічно-соціального комунікативно-когнітивного мемного спілкування землян на універсальне соціальне міжетнічне, започатковане на мемному рівні формуванням письма. Їх далекоглядність і несучасність лише тепер здаються внутрішньо несумісними: багатогранний учений, поліглот, що співпрацював з ідеологами світового єднання акад. М. Я. Марр, високоосвічений російський шовініст, прихильник загальнослов'янського об'єднання навколо православнохристиянської імперії Росії, що відвідав батьківщину основоположника генетики, голова повітового зібрання дворян, несамовитий приборкувач селян поміщик П.Я. Лукашевич i, нарешті, поверхово обізнаний у мовознавстві, військовий перекладач-арабіст, просякнутий шовінізмом на етапі утвердження СРСР в арабському світі М. М. Вашкевич. До речі, кожен з них у сучасників поставав якщо не диваком (Вашкевич, за свідченням відгуків в інтернеті), то психічно хворим (за спогадами сучасників-дворян у часи, коли публікував свої заумкуваті книги П. Я. Лукашевич) або взагалі хворим психічно, за атестацією одного радянського теоретика мовознавства, що заперечував спадок акад. М. Я. Мappa).

\section{Література}

1. Вашкевич Н. Системные знаки мозга. 2-е изд. Москва: Белые альвы, 2002. $400 \mathrm{c}$.

2. Гроть Н. Я. Психологія чувствованій въ ея исторіи и главныхъ основахъ. Санкть-Петербург:: Типографрія императорской академіи наукъ, $1879-1880$.

3. Гротъ Н. Я. Къ вопросу о рефрормЂ логики: Опыть новой теоріи умствђнныхъ процессов. Изданіе института Ф. А. Брокгауза въ Лейпцигち, 1882. $394 \mathrm{c}$.

4. Докінз Річард. Егоїстичний ген / пер. з англ. Харків: Клуб сімейного дозвілля, 2017. 544 с.

5. Зеленько А. С., Зеленько О. А. Микола Гоголь і художній контекст в аспекті когнітивної психології і лінгвістики. Література і культура Полісся. Ніжин: НДУ ім. М. Гоголя, 2018. Вип. 93. Серія "Філологічні науки". № 11. C. 125-137. 
6. Зеленько А. С., Бондар Н. О. Психологічне обґрунтування теорії і практики художнього перекладу. Література і культура Полісся. Ніжин: НДУ ім. М. Гоголя, 2018. Вип. 95. Серія "Філологічні науки". № 12. С. 226-236.

7. Клипа Н. І. Лінгвопсихологічна міжпредметність у визначенні проблематики мовної діяльності в курсі загального мовознавства. Література $i$ культура Полісся. Ніжин: НДУ ім. М. Гоголя, 2019. Вип. 95. Серія "Філологічні науки". № 12. С. 127-133.

8. Костюк Г. С. К вопросу о психологических закономерностях. Вопросы психологии. 1955. № 1. С. 19-28.

9. Костюк Г. С. Методологические и теоретические проблемы психологии / отв. ред. Е. В. Шорохова. Москва, 1988.

10. Кошелев А. Д. Об основных парадигмах изучения естественного языка в свете современных данных когнитивной психологии. Вопросы психологии. 2008. № 4. С. 15-46.

11. Кэролайн Лиф. Включите свой мозг / пер. с англ. Киев: Брайн Стар Паблишинг, 2017. 176 с.

12. Лукашевичъ П. Я. Примеръ всесвБтнаго славянскаго чаромутія въ словБ млжъ, открытый и составленный Платономъ Лукашевичемъ. Кіевъ, 1850.

13. Лукашевичъ П. Я. Примеръ всесвБтнаго славянскаго чаромутія обратнаго чтенія названій буквъ алфравитовъ греческаго и коптскаго. Москва: Университетская типографрія, 1855.

14. Марр Н. Я. Избранные работы. Москва: Политиздат, 1936.

15. Методологія та організація наукових досліджень: навч посіб. / І. С. Добронравова, О. В. Руденко, Л. С. Сидоренко та ін.; за ред. І. С. Добронравової (ч. 1), О.В.Руденко (ч. 2). Київ: ВПЦ "Київський університет", 2018. 607 c.

16. Челпановъ Г. Проблема воспріятія пространства въ связи съ ученіемъ об апріорности и врожденности. Кіевъ, 1896. Часть I: Представленіе пространства съ точки зрьнія психологіи. 395 с.

17. Челпановъ Г. Проблема воспріятія пространства въ связи съ ученіемъ об апріорности и врожденности. Кіевъ, 1904. Часть II: Представленіе пространства съ точки зрБнія гносеологіи. 129 с.

18. Экебладъ X. А. Опыть обозрБнія биолого-психологическаго изсльдованія способностей человеческаго духа. Москва, 1872. 462 с.

19. Paul McKenna Ph. D. Change your life in seven days / ed. by Michael Neie. Bantam. Press, 2010. 256 p.

\section{References}

1. Vashkevych, N. (2002). Systemnye znaky mozgha [System signs of brain]. (2nd ed.). Moskva: Belye alvy [in Russian].

2. Grot, N. Ya. (1879-1880). Psihologiya chuvstvovanij v eya istorii i glavnyh osnovah [Psychology of feelings in its history and main basics]. Sankt-Peterburg: Tipografiya imperatorskoj akademii nauk [in Russian].

3. Grot, N. Ya. (1882). K voprosu o reforme logiki: Opyt novoj teorii umstvtnnyh processov [K voprosu o reforme logiki: Opyt novoj teorii umstvennyh processov]. Izdanie instituta F. A. Brokgauza v Lejpcige [in Russian]. 
4. Dokinz, R. (2017). Ehoistychnyi hen [Selfish gene]. Kharkiv: Klub simeinoho dozvillia [in Ukrainian].

5. Zelenko, A. S., \& Zelenko, O. A. (2018). Mykola Hohol i khudozhnii kontekst v aspekti kohnityvnoi psykholohii i linhvistyky [Nikolai Gogol and the artistic context in the aspect of cognitive psychology and linguistics]. Literatura $i$ kultura Polissia - Literature and Culture of Polesie. Nizhyn: NDU im. M. Hoholia, Vol. 93, 11. 125-137 [in Ukrainian].

6. Zelenko, A. S., \& Bondar, N. O. (2018). Psykholohichne obgruntuvannia teorii i praktyky khudozhnoho perekladu [Psychological substantiation of the theory and practice of artistic translation] Literatura $i$ kultura Polissia - Literature and Culture of Polesie. Nizhyn: NDU im. M. Hoholia, Vol. 95, 12, 226-236 [in Ukrainian].

7. Klypa, N. I. (2019). Linhvopsykholohichna mizhpredmetnist u vyznachenni problematyky movnoi diialnosti $v$ kursi zahalnoho movoznavstva [Linguistic Psychological Intersubject in Determining Problems of Language Activity in General Linguistics] Literatura i kultura Polissia - Literature and Culture of Polesie. Nizhyn: NDU im. M. Hoholia, Vyp. 95, 12, 127-133 [in Ukrainian].

8. Kostyuk, G. S. (1955). K Voprosu o psihologicheskih zakonomernostyah [The question of psychological patterns] Voprosyi psihologii - Psychology Issues, 1. 19-28 [in Russian].

9. Kostyuk, G. S. (1988). Metodologicheskie i teoreticheskie problemyi psihologii [Methodological and theoretical problems of psychology]. E. V. Shorohova (Ed.). Moskva, 1988 [in Russian].

10. Koshelev, A. D. (2008). Ob osnovnyih paradigmah izucheniya estestvennogo yazyika v svete sovremennyih dannyih kognitivnoy psihologii [On the basic paradigms of natural language learning in the light of modern cognitive psychology data] Voprosyi psihologii - Psychology Issues, 4. 15-46 [in Russian].

11. Kerolayn, L. (2017). Vklyuchite svoy mozg [Turn on your brain]. Kiev: Brayn Star Pablishing [in Russian].

12. Lukashevich, P. Ya. (1850). Primer vsesvitnago slavyanskago charomutiya $v$ slovi mazh. otkrytyy i sostavlennyy Platonom Lukashevichem [An example of the all-Slavic Slavic charomutia in words mopgp, open and compiled by Platon Lukashevich]. Kiev [in Russian].

13. Lukashevich, P. Ya. (1855). Primer vsesvitnago slavyanskago charomutiya obratnago chteniya nazvaniy bukv alfavitov grecheskago $i$ koptskago [Example of all-Slavic Slavic charomuty reverse reading the name of the letters of the Greek and Coptic alphabets]. Moskva: Universitetskaya tipografiya [in Russian].

14. Marr, N. Ya. (1936). Izbrannyie rabotyi [Selected Works]. Moskva: Politizdat [in Russian].

15. Dobronravova, I. S., Rudenko, O. V., \& Sydorenko, L. S. (2018). Metodolohiia ta orhanizatsiia naukovykh doslidzhen [Methodology and organization of scientific research]. I. S. Dobronravova, O. V. Rudenko (Ed.). Kyiv: VPTs "Kyivskyi universytet" [in Ukrainian].

16. Chelpanov, G. (1896). Problema vospriyatiya prostranstva $v$ svyazi $s$ ucheniem ob apriornosti i vrozhdennosti [The problem of reproduction of space in connection with learning about apriority and congenitality]. Kiev. (Vol. I) [in Russian]. 
17. Chelpanov, G. (1904). Problema vospriyatiya prostranstva $v$ svyazi $s$ ucheniem ob apriornosti i vrozhdennosti [The problem of reproduction of space in connection with learning about apriority and congenitality]. Kiev. (Vol. II) [in Russian].

18. Ekeblad, H. A. (1872). Opyt obozreniya biologo-psihologicheskago izsledovaniya sposobnostej chelovecheskago duha [Experience in reviewing the biological, psychological and psychological studies of the abilities of the human spirit]. Moskva [in Russian].

19. Paul McKenna Ph. D. Change your life in seven days / ed. by Michael Neie. Bantam. Press, 2010. 256 p.

\section{O. A. Zelenko}

Candidate of Medical Sciences,

Associate Professor of the department of general psychology

Kyiv National University of Taras Shevtchenko

\section{On about the functional of the forming of the psychological activities of the stage of the forming of the consciousness}

The author defines the two problems white connected between them. One problem is general social, second problem is particular scientifical psychological. They connects the problems are actual and must be decide according the principles of the scientific character. This causes by the dominance of the populazal popularism of the soviet bureacratizm. The author predetermines the decision of the promlem by forming of the methodology of the social pedology. This methodology bases on the triplicity interpretation of the pithy structure of the cathegory of the consciousness. This cathegory untropologicatization with the cathegory of the elitnic. The elitnic must be form in the modernization university according social-lewel principl of the transformation of the hight school. The graduates of this university must be substitute the bureaucratic funkcionaters. In the article underlines also the intersubjectical character of the decision of the naned problems.

Key words: consciousness, democratization, elitnic, izomorfixm, cognitivizm, reforming, transformation. 